\title{
Perception of Foreign Tourists to Karawo Embroidery Handicrafts in Gorontalo Tourist Destinations
}

\author{
Anggraeni M. S Lagalo ${ }^{1}$, Nur Fadhlya Usu ${ }^{2}$ \\ ${ }^{1}$ Lecturer of Tourism Study Program, Muhammadiyah University of Gorontalo, Indonesia \\ ${ }^{2}$ Students of Tourism Study Program, Muhammadiyah University of Gorontalo, Indonesia \\ Received: July 10, 2020 \\ Revised: August 8, 2020 \\ Accepted: August 13, 2020
}

\begin{abstract}
The purpose of this study was focused on knowing the perceptions of tourists, both foreign tourists, about the craft of Karawo embroidery in Gorontalo Tourism Destinations. This research method using a quantitative approach itself is carried out using a questionnaire given to the public and tourists who visit the Karawo embroidery craft center. The sampling technique in this study used a non-probability or non-random sample selection technique. The results showed that the quantitative approach itself was carried out using a questionnaire given to the public and tourists who visited the Karawo embroidery craft center. The sampling technique in this study used a non-probability or non-random sample selection technique. The results of this study indicate that the Karawo embroidery craft has the potential to be developed as a tourist attraction in Gorontalo Province. Analysis of the attractiveness and perceptions of tourists who visit the Karawo embroidery craft center as well as the local community provide direction on the development of tourist attractions that are related to cultural aspects. The perception of foreign tourists in general gives a positive value to Karawo embroidery and argues that Karawo embroidery is unique from the manufacturing process and has its own characteristics with very beautiful motif designs.
\end{abstract}

Keywords: Perception of Tourists, Foreign Tourists, Embroidery Craft

\section{Introduction}

Tourism has now become one of the largest industries in the world. In addition, it is also a mainstay for many countries in generating foreign exchange, creating jobs, as well as reducing poverty. Tourism with its various positive aspects is seen as a passport to development, new kind of sugar, tool for regional development, invisible export, non-polluting industry, and many others (Pitana \& I Ketut, 2009; Kurnianto et al., 2013; Wibowo et al. ., 2017; Syahrial \& Badollahi, 2020).

The tourism development plan is realized through taking into account the diversity, uniqueness, and uniqueness of culture and nature as well as human needs for tourism (Rizal, 2021; Csapó, 2012; Faganel \& Trnavčevič, 2012). Sustainable development and community-based development are the basis of tourism. Indonesia has a diversity of tourism potential spread in every tourist destination. Therefore, the diversity of tourism potential owned by Indonesia must be maintained and developed. Because it can have a positive impact on the economy, the preservation of arts and culture in the Tourism Law No. 10 of 2009.

Gorontalo Province currently has many tourist attractions spread throughout the regencies and cities. There are 86 tourism objects where there are categories of natural tourism, artificial tourism, as well as categories of cultural tourism and historical heritage. In addition to having a lot of potential and tourist attractions in Gorontalo, there are also various unique features that 
are not owned by other provinces in Indonesia, including works of art and culture that have a distinctive feature, namely Embroidery Karawo.

An art and culture is usually a support in the various tourist attractions offered in a tourism destination. However, in Gorontalo, one of the works of art and culture can play a double role as a regional souvenir and as a tourist attraction. The work of art and culture is Karawo embroidery. Karawo embroidery is an expression of traditional culture in the form of embroidery that is passed down from generation to generation and is considered to have a high artistic aesthetic (Dai, 2016).

Karawo embroidery is one of the cultural arts of Gorontalo produced through the embroidery process by pulling/untying the threads of the fabric to form a certain pattern. The results of Karawo crafts are mostly in the form of cloth for clothes/coats, mukenah, headscarves, hand fans, handkerchiefs, tablecloths, ties, and others. The artistic value and level of complexity in the process of making Karawo handicrafts are the same as Javanese batik, but the popularity of karawo is still far from the popularity of Javanese batik. This is because the motifs commonly used in Karawo crafts are still limited to floral, fruit or logo motifs of a particular agency, besides that Karawo is only used on certain occasions, such as official government events and big days so that Karawo is less popular in the community (Koniyo, et al, 2015).

The development of Karawo embroidery in Gorontalo Province is considered to be a potential attraction because of its long history and uniqueness in the process of making Karawo embroidery. For the development and preservation of Karawo, the government held a Karawo cultural festival. The cultural festival has become an annual agenda for the provincial government and has been carried out on a large scale since 2011 until now. The government's goal in implementing this festival is to promote Karawo embroidery and make Karawo embroidery worldwide.

The actualization of Karawo embroidery to the world level indirectly becomes the promotion of Gorontalo tourism so that there is hope that Karawo embroidery can bring domestic tourists and foreign tourists to Gorontalo. Based on the description of the background exposure, the researchers conducted research on "Foreign Tourists' Perceptions of Karawo Embroidery Crafts in Gorontalo Tourism Destinations". This research on the perception of foreign tourists towards Karawo embroidery is important to be able to be used as study material in the development of tourist attractions and increasing the number of tourist visits in Gorontalo Tourism Destinations. The purpose of this study was focused on knowing the perceptions of tourists, both foreign tourists, about the craft of Karawo embroidery in Gorontalo Tourism Destinations.

\section{Methods}

This research was conducted in Gorontalo Province, precisely in Mongolato Village, Telaga District, Gorontalo Regency which is the Karawo Embroidery Craft Center. This study uses a descriptive quantitative approach. This study describes the questionnaire data obtained from the results of research on Tourist Perceptions of Karawo Embroidery Crafts at Gorontalo Tourism Destinations.

The quantitative approach itself is carried out using a questionnaire given to the public and tourists who visit the Karawo embroidery craft center.

The sampling technique in this study used a non-probability or non-random sample selection technique. The sample selection in this study used the Incidental Sampling method. Respondents in this study were foreign tourists. The respondent determination technique is incidental sampling or by chance. This study used 30 questionnaires for 30 foreign tourists. At

Copyright $@$ 2020, Journal of Asian Multicultural Research for Economy and Management Study, Under the license CC BY-SA 4.0 
a coincidental meeting with the tourist, the tourists were asked to fill out a questionnaire. In this study, it is not only asking tourists to fill out questionnaires, but also if tourists are willing they can be asked for time for a brief interview. The second analysis technique uses a Likert Scale, the type of data analyzed is quantitative data. The Likert scale is used to measure and analyze foreign tourists' perceptions of karawo embroidery in Gorontalo tourist destinations

The formula used is as follows (Dajan, 1996) (in Widuri, 2012):

Description: $\mathrm{R}=$ Highest score - lowest score

$$
\text { Interval }=\frac{R}{K}
$$

$\mathrm{K}=$ Number of rating scales

$$
\frac{5-1}{5}=0,8
$$

\section{Results and Discussion}

Through embroidery motifs, done on fabrics using plain or colorful threads. The process of making this karawo embroidery is by slicing and pulling the thread from the finished fabric fiber and then embroidering it with a needle with various threads according to the desired pattern / motif design by hand (manual). To make a karawo embroidery pattern, it takes three people with different tasks.

\section{Results of Analysis of Tourists' Perception of Karawo Embroidery Craft}

Tourists are the target of a tourist attraction. Various infrastructures are created and improved to support a tourist attraction in order to meet the needs of tourists while they are traveling. When tourists have a positive view of the tourist attraction they visit, it should be maintained and even improved because it will have an impact on the existence of the tourist attraction itself. Related to the Karawo embroidery as an attraction that is currently being developed and even promoted by the Gorontalo government, knowing the perceptions or views of tourists about Karawo embroidery is very important. The method used to determine the perception of tourists is by distributing questionnaires. The distribution of questionnaires in the study was carried out at the Karawo Embroidery Craft Center.

At the time the questionnaire was distributed, tourists were also briefly interviewed. The results of distributing the questionnaires were then linked to the perceptions of tourists which were expressed verbally through the short interviews. Foreign tourists assume that Karawo embroidery is a handicraft typical of the Gorontalo region which is unique and reflects the creativity of the local community, especially the ancestors who inherited this embroidery art. In general, foreign and domestic tourists also state that Karawo embroidery is a very beautiful work of art.

\section{Perception of Foreign Tourists to Karawo Embroidery Craft}

Table 1. Perception of Foreign Tourists on Karawo Embroidery Craft

\begin{tabular}{|c|l|c|c|c|c|c|}
\hline \multirow{2}{*}{ No } & \multicolumn{1}{|c|}{$\begin{array}{c}\text { Foreign Tourist } \\
\text { Perception }\end{array}$} & \multicolumn{4}{|c|}{ Number of Tourist } \\
\cline { 3 - 7 } & $\begin{array}{c}\text { Value } \\
\text { Weight } \\
\mathbf{5}\end{array}$ & $\begin{array}{c}\text { Weight } \\
\text { Value 4 }\end{array}$ & $\begin{array}{c}\text { Value } \\
\text { Weight } \\
\mathbf{3}\end{array}$ & $\begin{array}{c}\text { Weight } \\
\text { Value 2 }\end{array}$ & $\begin{array}{c}\text { Weight } \\
\text { Value 1 }\end{array}$ \\
\hline 1 & $\begin{array}{l}\text { The uniqueness of Karawo } \\
\text { embroidery }\end{array}$ & 10 & 0 & 0 & 0 & 0 \\
\hline
\end{tabular}




\begin{tabular}{|c|c|c|c|c|c|c|}
\hline 2 & $\begin{array}{l}\text { The potential of Karawo } \\
\text { embroidery craft as a tourist } \\
\text { attraction }\end{array}$ & 10 & 0 & 0 & 0 & 0 \\
\hline 3 & $\begin{array}{l}\text { Improved quality and } \\
\text { design of motifs on Karawo } \\
\text { embroidered fabrics }\end{array}$ & 9 & 1 & 0 & 0 & 0 \\
\hline 4 & $\begin{array}{l}\text { Improving the quality of } \\
\text { service at karawo } \\
\text { embroidery center }\end{array}$ & 10 & 0 & 0 & 0 & 0 \\
\hline 5 & $\begin{array}{l}\text { The need for the } \\
\text { development of tourist } \\
\text { attraction packages related } \\
\text { to karawo embroidery } \\
\text { crafts }\end{array}$ & 9 & 1 & 0 & 0 & 0 \\
\hline 6 & $\begin{array}{l}\text { Training on making } \\
\text { Karawo embroidery crafts } \\
\text { to the community }\end{array}$ & 10 & 0 & 0 & 0 & 0 \\
\hline 7 & $\begin{array}{l}\text { Hospitality of both } \\
\text { craftsmen and businesses to } \\
\text { visitors in karawo } \\
\text { embroidery craft center }\end{array}$ & 5 & 5 & 0 & 0 & 0 \\
\hline 8 & $\begin{array}{l}\text { Karawo embroidery } \\
\text { craftsmen are willing to be } \\
\text { tour guides to tourists who } \\
\text { need it }\end{array}$ & 5 & 5 & 0 & 0 & 0 \\
\hline 9 & $\begin{array}{l}\text { Karawo embroidery } \\
\text { craftsmen always try to } \\
\text { provide the needs of } \\
\text { tourists who visit the center } \\
\text { of karawo embroidery } \\
\text { crafts }\end{array}$ & 9 & 1 & 0 & 0 & 0 \\
\hline 10 & $\begin{array}{l}\text { There needs to be a strategy } \\
\text { to develop Karawo } \\
\text { embroidery as a tourist } \\
\text { attraction }\end{array}$ & 9 & 1 & 0 & 0 & 0 \\
\hline
\end{tabular}

Source : Kusmayadi \& Sugiarto (2000) and Research Results (2018).

Based on Table 5.1, most foreign tourists think that Karawo embroidery is very unique, the assessment comes from as many as 10 tourists from a total of 10 foreign tourist respondents. Then it was assessed as a potential tourist attraction from 10 tourists out of a total of 10 foreign tourist respondents, by improving the quality and design of motifs on Karawo embroidered fabrics, derived from the assessment of 9 tourists from a total of 10 foreign tourists who were respondents in the study this.

In brief interviews, foreign tourists argue that there is a special characteristic of the Karawo embroidery so that it can attract the attention of visiting tourists. However, there were 10 tourists out of a total of 10 foreign tourist respondents who considered the need to improve the quality of service at the Karawo embroidery craft center for the convenience of visiting tourists. 
Karawo embroidery is considered a potential tourist attraction, but it is necessary to develop a tour package related to Karawo embroidery, especially a tourist attraction. The assessment came from 9 tourists from a total of 10 foreign tourist respondents. Foreign tourists also give a positive value to the facilities provided at the Karawo embroidery craft center, tourists think that these facilities are quite complete and adequate.

According to 10 tourists, in terms of overall respondents from foreign tourists, there needs to be training in making Karawo embroidery for the local community, for the regeneration of Karawo embroidery craftsmen. From the results of short interviews, foreign tourists also argue that the uniqueness of the Karawo embroidery craft is in the manufacturing process.

According to tourists, the process of making Karawo embroidery is interesting and challenging, namely the section on slicing and pulling the fabric fibers because it requires precision in doing so. Meanwhile, foreign tourists also gave a positive assessment of the friendliness of the craftsmen and business actors at the Karawo embroidery craft center. The positive assessment came from 5 tourists out of a total of 10 foreign tourist respondents who were respondents in this study. A total of 5 tourists out of a total of 10 foreign tourist respondents considered that Karawo embroidery craftsmen were always willing to be tour guides for tourists who needed them.

The Karawo embroidery craftsmen also always try to provide the needs of tourists visiting the Karawo embroidery craft center. The positive assessment comes from the opinions of 9 tourists from a total of 10 foreign tourist respondents in this study. There were as many as 9 tourists from a total of 10 respondents of foreign tourists related to the potential of Karawo embroidery as a tourist attraction, the foreign tourists stated that there was a need for a strategy to develop Karawo embroidery as a tourist attraction.

Table 2. Results of Research on Perception of Foreign and Domestic Tourists on Karawo Embroidery Craft

\begin{tabular}{|c|l|c|c|c|c|c|}
\hline \multirow{2}{*}{ No } & \multicolumn{1}{|c|}{$\begin{array}{l}\text { Traveller Perception } \\
\text { Foreign }\end{array}$} & \multicolumn{4}{|c|}{ Number of Travellers } \\
\cline { 3 - 7 } & $\begin{array}{c}\text { Value } \\
\text { Weight } \\
\mathbf{5}\end{array}$ & $\begin{array}{c}\text { Weight } \\
\text { value 4 }\end{array}$ & $\begin{array}{c}\text { Value } \\
\text { Weight } \\
\mathbf{3}\end{array}$ & $\begin{array}{c}\text { Weight } \\
\text { value 2 }\end{array}$ & $\begin{array}{c}\text { Weight } \\
\text { value 1 }\end{array}$ \\
\hline 2 & $\begin{array}{l}\text { The uniqueness of } \\
\text { Karawo embroidery }\end{array}$ & 29 & 1 & 0 & 0 & 0 \\
\hline 3 & $\begin{array}{l}\text { The potential of Karawo } \\
\text { embroidery craft as a } \\
\text { tourist attraction }\end{array}$ & 24 & 6 & 0 & 0 & 0 \\
\hline & $\begin{array}{l}\text { Improved quality and } \\
\text { design of motifs on } \\
\text { Karawo embroidered } \\
\text { fabrics }\end{array}$ & 18 & 10 & 0 & 1 & 1 \\
\hline & $\begin{array}{l}\text { Improving the quality of } \\
\text { service at karawo } \\
\text { embroidery center }\end{array}$ & 25 & 3 & 0 & 2 & 0 \\
\hline
\end{tabular}




\begin{tabular}{|c|c|c|c|c|c|c|}
\hline 5 & $\begin{array}{l}\text { The need for the } \\
\text { development of tourist } \\
\text { attraction packages } \\
\text { related to karawo } \\
\text { embroidery crafts }\end{array}$ & 20 & 10 & 0 & 0 & 0 \\
\hline 6 & $\begin{array}{l}\text { Training on making } \\
\text { Karawo embroidery } \\
\text { crafts to the community }\end{array}$ & 26 & 3 & 0 & 1 & 0 \\
\hline 7 & $\begin{array}{l}\text { Hospitality of both } \\
\text { craftsmen and } \\
\text { businesses to visitors in } \\
\text { karawo embroidery } \\
\text { craft center }\end{array}$ & 18 & 11 & 1 & 0 & 1 \\
\hline 8 & $\begin{array}{l}\text { Karawo embroidery } \\
\text { craftsmen are willing to } \\
\text { be tour guides to tourists } \\
\text { who need it }\end{array}$ & 18 & 11 & 0 & 1 & 0 \\
\hline 9 & $\begin{array}{l}\text { Karawo embroidery } \\
\text { craftsmen always try to } \\
\text { provide the needs of } \\
\text { tourists who visit the } \\
\text { center of karawo } \\
\text { embroidery crafts }\end{array}$ & 23 & 6 & 0 & 1 & 0 \\
\hline 10 & $\begin{array}{l}\text { There needs to be a } \\
\text { strategy to develop } \\
\text { Karawo embroidery as a } \\
\text { tourist attraction }\end{array}$ & 22 & 7 & 1 & 0 & 0 \\
\hline
\end{tabular}

Source: Dajan (1996) and Research Results (2018).

Based on table 5.2 on the first indicator, it can be seen that most of the tourists gave positive assessments and responses that the Karawo embroidery craft was unique. The assessment can be described in the weighting of values (5) which states that the Karawo embroidery craft is very unique, namely as many as twenty-nine tourists $(96.7 \%)$, consisting of ten foreign tourists and nineteen domestic tourists. Next to assigning a weighting value (4), only one person from tourists $(3.3 \%)$ who are domestic tourists thinks that Karawo embroidery is unique. Meanwhile, there were no tourists who gave a value stating that Karawo embroidery was quite unique, not unique, and not very unique $(0.0 \%)$. The tourist attitude scale obtained is 149 with an average value of 4.97. The overall results from Table 4.6 on the first indicator show that foreign and domestic tourists generally think that Karawo embroidery is very unique.

\section{Potential of Karawo Embroidery as a Tourist Attraction}

Based on table 5.2 in the second indicator, for assigning a weighting value (5) there are twentyfour tourists $(80 \%)$ consisting of ten foreign tourists and fourteen domestic tourists. This assessment shows that most tourists think that Karawo embroidery has great potential as a tourist attraction. Then, the weight value (4) which states that Karawo embroidery has the potential as a tourist attraction is given by six tourists (20\%) which only consist of domestic tourists. Meanwhile, for the subsequent weighting of values as in the first indicator, there was no assessment from tourists stating that Karawo embroidery has potential as a tourist attraction, does not have the potential as a tourist attraction, and has no potential as a tourist attraction (0).

Copyright () 2020, Journal of Asian Multicultural Research for Economy and Management Study, Under the license CC BY-SA 4.0 
$0 \%$ ). Thus, it can be determined that the scale of tourist attitudes is 144 with an average value of 4.80. The overall results from table 4.6 in the second indicator show that in general tourists think that Karawo embroidery has great potential as a tourist attraction.

\section{Quality and Design Motifs on Karawo Embroidery Craft Fabrics}

Based on 5.3 on the third indicator, there are eighteen tourists $(60 \%)$ who give a weighted value of (5) consisting of nine foreign tourists and nine domestic tourists assessing the need to improve the quality and design of motifs on Karawo embroidered fabrics. Meanwhile, ten tourists (33\%) who gave a weighted value of (4), consisting of one foreign tourist and nine domestic tourists considered that it was necessary to improve the quality and design of motifs on Karawo embroidered fabrics. Furthermore, there is no rating from tourists $(0.0 \%)$ for sufficient weight (3). Meanwhile, there is one tourist (3.3\%) who gives a weighted value of (2), the assessment comes from domestic tourists. Tourists consider that there is no need to improve the quality and design of motifs on Karawo embroidered fabrics. Giving the lowest score (1) is given by one domestic tourist (3.3\%), the tourist believes that it is not necessary to improve the quality and design of motifs on Karawo embroidered fabrics. Thus, it can be determined that the scale of tourist attitudes is 133 with an average value of 4.43. The overall results from table 4.6 in this third indicator show that tourists generally think that it is necessary to improve the quality and design of motifs on Karawo embroidered fabrics.

\section{Quality Service at Karawo Embroidery Craft Center}

Based on table 4.6 in the fourth indicator, for assigning a weighting value (5) there are twentyfive tourists $(83.3 \%)$ consisting of ten foreign tourists and fifteen domestic tourists. This assessment shows that most tourists think that it is necessary to improve the quality of service at the Karawo embroidery craft center. Next, there are as many as three tourists (10\%) who give a weighted value of (4), the assessment only comes from domestic tourists. Tourists consider that it is necessary to improve the quality of service at the Karawo embroidery craft center. Meanwhile, none of the tourists $(0.0 \%)$ gave an assessment with a weighted value of (3). Furthermore, the weighting value (2) comes from two domestic tourists (6.7\%). The tourist thought that there was no need to improve the quality of service at the Karawo embroidery craft center. Finally, there is not a single tourist $(0.0 \%)$ who gives a weighted value of (1). Thus, it can be determined that the scale of tourist attitudes is 141 with an average value of 4.70 . The overall results from table 4.6 in the fourth indicator show that in general tourists think that it is necessary to improve the quality of service at the Karawo embroidery craft center.

\section{Karawo Embroidery Craft Tour Package Development}

Based on table 5.2 in the fifth indicator, there were as many as twenty tourists $(66.7 \%)$ giving a weighted value of (5) consisting of nine foreign tourists and eleven domestic tourists. Tourists consider that it is very necessary to develop a tourist attraction package related to the Karawo embroidery craft. Next, the weighting value (4) is given by ten tourists $(33.3 \%)$ consisting of one foreign tourist and nine domestic tourists. The assessment given shows that tourists think that it is necessary to develop a tourist attraction package related to the Karawo embroidery craft. Meanwhile, there was no rating from tourists $(0.0 \%)$ on the weighted value (3), the weighted value (2), and the weighted value (1). Thus, it can be determined that the scale of tourist attitudes is 140 with an average value of 4.67. The overall results from table 4.6 in the fifth indicator show that in general tourists think that it is necessary to develop a tourist attraction package related to the Karawo embroidery craft. 


\section{Training to Make Karawo Embroidery Craft to the Community}

Based on table 5.2 in the sixth indicator, for assigning a weighting value (5) there were as many as twenty-six tourists $(86.7 \%)$ consisting of ten foreign tourists and sixteen domestic tourists assessing that training in making Karawo embroidery is for the local community. is indispensable. Next, there were as many as three tourists (10.0\%) who gave a weighted value of (4), but the assessment only came from domestic tourists. Tourists consider that training in making Karawo embroidery for the community is considered necessary. Meanwhile, there was not a single tourist $(0.0 \%)$ who gave a weighted value of (3) in the sense that there was not a single tourist who thought that training in making Karawo embroidery for local communities was quite necessary. Meanwhile, there was only one tourist (3.3\%) who gave a weighted value of (2), namely from domestic tourists who thought that training in making Karawo embroidery for local communities was not necessary. Finally, there is not a single tourist $(0.0 \%)$ who gives a weight rating of (1). Thus, it can be determined that the scale of tourist attitudes is 144 with an average value of 4.80. The overall results of table 4.6 on the sixth indicator show that in general tourists think that training in making Karawo embroidery for local communities is very necessary.

\section{Hospitality of Craftsmen / BusinessEs to Visitors at Karawo Embroidery Craft Center}

Based on table 5.2 in the seventh indicator, there are as many as eighteen tourists (60\%) giving a weighted value of (5) consisting of five foreign tourists and thirteen domestic tourists. Tourists consider that craftsmen and business people are very friendly to visitors at the Karawo embroidery craft center. Next, the weighting value (4) is given by eleven tourists $(36.7 \%)$ consisting of five foreign tourists and six domestic tourists. The assessment given shows that tourists think that craftsmen and business actors are friendly to visitors at the Karawo embroidery craft center. Meanwhile, for giving the weighting value (3) only comes from one domestic tourist (3.3\%), tourists assess that both craftsmen and business actors are quite friendly to visitors at the Karawo embroidery craft center. Meanwhile, there was not a single tourist $(0.0 \%)$ who gave a weighted value of (2), nor a weighted value of (1). Thus, it can be determined that the scale of tourist attitudes is 137 with an average value of 4.57 . The overall results of table 4.6 on the seventh indicator show that in general tourists think that both craftsmen and business actors are very friendly to visitors at the Karawo embroidery craft center.

\section{Karawo Embroidery Craftsmen Willing to Be Tour Guides}

Based on table 5.2 in the eighth indicator, for assigning a weighting value (5) there are eighteen tourists $(60 \%)$ consisting of five foreign tourists and thirteen domestic tourists assessing that the Karawo embroidery craftsmen are very willing to be tour guides for tourists. requiring. Next, there were eleven tourists (36.7\%) who gave a weighted value of (4), consisting of five foreign tourists and six domestic tourists. Tourists consider that Karawo embroidery craftsmen are willing to be tour guides for tourists in need. Meanwhile, there is not a single tourist $(0.0 \%)$ who gives a weight value of (3) in the sense that there is not a single tourist who thinks that Karawo embroidery craftsmen are quite willing to be a tour guide for tourists in need. Meanwhile, there is only one tourist (3.3\%) who gives a weighted value of (2), which is from domestic tourists who think that Karawo embroidery craftsmen are not willing to be tour guides for tourists in need. Finally, there is not a single tourist $(0.0 \%)$ who gives a weight rating of (1). Thus, it can be determined that the scale of tourist attitudes is 136 with an average value of 4.53. The overall results of table 5.2 on the eighth indicator show that in general tourists think that Karawo embroidery craftsmen are very willing to be tour guides for tourists in need. 


\section{Karawo Embroidery Crafts Craftsmen Trying to Provide Tourist Needs at Karawo Embroidery Craft Center}

Based on table 5.2 on the ninth indicator, there are as many as twenty-three tourists $(76.7 \%)$ giving a weighted value of (5) consisting of nine foreign tourists and fourteen domestic tourists. The tourists considered that the Karawo embroidery craft craftsmen really tried to provide the needs of tourists visiting the Karawo embroidery craft center. Next, the weighting value (4) is given by six tourists (20\%) consisting of one foreign tourist and five domestic tourists. The assessment given shows that tourists think that Karawo embroidery craftsmen try to provide the needs of tourists visiting the Karawo embroidery craft center. Meanwhile, there is not a single tourist $(0.0 \%)$ who gives a weighted value of (3) in the sense that there is not a single tourist who thinks that Karawo embroidery craftsmen are enough to provide the needs of tourists visiting the Karawo embroidery craft center. Meanwhile, there is only one tourist $(3.3 \%)$ who gives a weighted value of (2), which is from domestic tourists who think that Karawo embroidery craftsmen do not always try to provide the needs of tourists visiting the Karawo craft center. Finally, there is not a single tourist $(0.0 \%)$ who gives a weight rating of (1). Thus, it can be determined that the scale of tourist attitudes is 141 with an average value of 4.70. The overall results of table 5.2 on the ninth indicator show that tourists generally think that Karawo embroidery craftsmen are always trying to provide the needs of tourists visiting the Karawo embroidery craft center.

\section{The Need for Karawo Embroidery Craft Development Strategy as a Tourist Attraction}

Based on table 5. in the tenth indicator, for assigning a weighting value (5) there are twentytwo tourists $(73.3 \%)$ consisting of nine foreign tourists and thirteen domestic tourists assessing that there is a strategy for developing Karawo embroidery as a tourist attraction is considered very necessary. Next, there were as many as seven tourists $(23.3 \%)$ who gave a weighted value of (4), consisting of one foreign tourist and six domestic tourists. Tourists consider that there is a need for a strategy for developing Karawo embroidery as a tourist attraction. Meanwhile, for giving the weighting value (3) only comes from one domestic tourist (3.3\%), tourists consider it sufficient to have a strategy for developing Karawo embroidery as a tourist attraction. Meanwhile, there was not a single tourist (0.0\%) who gave a weighted value of (2), nor a weighted value of (1).

Thus, it can be determined that the scale of tourist attitudes is 141 with an average value of 4.70. The overall results of table 5.2 on the tenth indicator show that in general tourists think that it is very necessary to develop a strategy for developing Karawo embroidery as a tourist attraction.

\section{Conclusion}

Karawo embroidery has the potential to be developed as a tourist attraction in Gorontalo Province. Analysis of the attractiveness and perceptions of tourists who visit the Karawo embroidery craft center as well as the local community provide direction on the development of tourist attractions that are related to cultural aspects. The perception of foreign tourists in general gives a positive value to Karawo embroidery and argues that Karawo embroidery is unique in terms of the manufacturing process and has its own characteristics with very beautiful motif designs and has the potential to be developed as a tourist attraction. In addition to tourists, the community around the Karawo embroidery craft center also generally gives a positive assessment of the development of Karawo embroidery as a tourist attraction. 


\section{References}

Csapó, J. (2012). The role and importance of cultural tourism in modern tourism industry. Strategies for tourism industry-micro and macro perspectives, 201-232.

Dai, S.L., (2016), Pengembangan Sulaman Karawo sebagai Daya Tarik di Destinasi Pariwisata Gorontal. Thesis. Bali: UNUD.

Dajan, A., (1996), Pengantar Metode Statistik Jilid II (cetakan kedelapan belas), Jakarta: PT. Pustaka LP3ES.

Faganel, A., \& Trnavčevič, A. (2012). Sustainable natural and cultural heritage tourism in protected areas: case study. Annales: Series historia et sociologia, 22(2), 589-600.

Kurnianto, B. T., Sugiyanto, K. H., \& Sukesi, K. (2013). Agrotourism Development Strategies Based on Institutional at Wonorejo Reservoir, Tulungagung, East Java, Indonesia. $J$. Environ. Earth Sci, 3, 11-17.

Kusmayadi \& Sugiarto, E., (2000), Metodologi Penelitian dalam Bidang Kepariwisataan, Jakarta: PT. Gramedia Pustaka Utama.

Pitana, I. G., \& I Ketut, S. D. (2009). Pengantar Ilmu Pariwisata. Yogyakarta: Penerbit ANDI.

Rizal, A. (2021). Implementation of Tourism Development Policies in Garut District, West Java Province, Indonesia. The Institute of Biopaleogeography named under Charles R. Darwin, 5, 1-40.

Syahrial, S., \& Badollahi, M. Z. (2020). Development of a Community-Based Marine Tourism Attraction in the Samboang Beach in Bulukumba Regency. Journal La Bisecoman, 1(2), 1-9.

Wibowo, S., Rusmana, O., \& Zuhelfa, Z. (2017). Pengembangan Ekonomi Melalui Sektor Pariwisata Tourism. Jurnal Kepariwisataan: Destinasi, Hospitalitas dan Perjalanan, 1(2), 93-99. 